\title{
Pre-Service STEM Teachers and Their Enactment of Community-STEM- Project Based Learning (C-STEM-PBL)
}

\author{
Imelda Nava \\ University of California \\ Jaime Park \\ University of California
}

Effective K-12 STEM teachers are essential to the critical analysis of real-world issues and can contribute to the democratization of our society. Thus, we engage pre-service math and science teachers in communityfocused STEM project-based learning (C-STEM-PBL) so they can integrate community assets, voices, and needs into their pedagogical practice. In this context, pre-service STEM teachers engage K-12 students by connecting STEM-related issues to their personal and community experiences. Further, this place-based, high context approach creates opportunities for critical analysis; so, students might push against the injustices that affect the community. This model presents access to the third space of teacher development, one with the potential to engage urban situated STEM teachers in the community.

Keywords: teacher education program, STEM education, community, urban schools

\section{RESEARCH QUESTION}

How do pre-service STEM teachers enact community-centered project-based learning pedagogy in urban marginalized settings?

\section{THEORETICAL FRAMEWORK}

Humanizing pedagogy (Bartolomé, 1994), culturally relevant pedagogy (Ladson-Billings, 2009), and what it means to be a community teacher (Murrell, 2000) anchor the work of C-STEM-PBL. Teachers practice humanizing pedagogy by interacting with their students with care and fostering independence, resilience, and persistence. Thus, teachers see, hear and integrate student voices into their classroom community (Bartolomé, 1994). Culturally relevant pedagogy is grounded in 1) supporting student learning through pedagogy, 2) cultural competence, 3) socio-political consciousness that has potential for critical reflection and action (Ladson-Billings, 2009). Murrell (2000) defines a community teacher as the following. "A community teacher develops the contextualized knowledge of culture, community, and identity of the children and their families as the core of their teaching practice.... A significant part of this context is the candidate's own cultural, political, and racial identity. These determine how central or peripheral they are concerning the core practices of a group or community that result in the successful development of children and youth" Murrell, 2000 pg. 340. 
Given these theoretical frames, we support teacher learning through enactment and critical reflection tied to theory. Engerström (2001), notes that learning takes place in the doing and the tensions that exist in that space. Preservice teachers learn when they enact and reflect within the complexity of the university and field spaces. Kretchmar and Zeichner (2016) propose the 3rd generation of teacher preparation, one that connects the framework of a community teacher with theory, critical reflection, and practice in authentic, collaborative, and responsive ways. This allows for the democratization of teacher education in a third space of deep learning (Zeichner, Payne, and Brayko, 2015). Darling-Hammond and Oaks (2019) characterize deep learning in teacher education by the following: 1) learning that is developmentally grounded and personal, 2) learning that is contextualized, 3) learning that is applied and transferred, 4) learning that occurs in productive communities of practice, and 5) learning that is equitable and grounded in social justice. Thus, C-STEM-PBL has the potential to deepen both pre-service teacher and K-12 student learning.

\section{STEM and PBL}

PBL is grounded in cognitive theory and stems from an instructional approach identified as the project method, developed by Kilpatrick (1918) and Dewey (1938). In this case, students are active investigators. Larmer, Mergendoller \& Boss (2015) define the gold standard of PBL as having key knowledge and understanding and key success skills at the center, with the following elements supporting that larger goal: 1) challenging problem or question, 2) sustained inquiry, 3) authenticity, 4) student voice and choice, 5) reflection, 6) critique and revision and 7) public product.

STEM-PBL has demonstrated positive results in self-efficacy, self-confidence and interest in learning was also improved, specifically given collaboration and tasks rooted in students' experiences (Baran \& Maskan, 2010). Kaldi, Filippatou, \& Govaris, (2011) noted that hands-on learning and field-based experiences were foremost in increasing content knowledge and attitudes for learning. Further, learning, collaboration, and communication were positively affected (Dominguez \& Jaime, 2010; Kaldi \& Filippatou \& Govaris, 2011). There is emerging evidence that PBL improves both math and science achievement in low-performing youth (Geimer, 2014; Han, R. Capraro \& M. Capraro, 2014). More specifically, increased achievement levels were found among underrepresented minorities, specifically Hispanics (Han, Capraro, \& Capraro, 2015; Han, Capararo, \& Capararo, 2016). The gold standard of PBL, the principles of deep learning, and how people learn complement C-STEM-PBL. Further, Weissmann, Ibarra, Howland-Davis, \& Lammey (2019) argue that high context learning vs. low context learning might be more effective for URM. This work is centered in urban settings in school-wide Title 1 schools. We focus on how pre-service teachers connect a community component to PBL that fosters greater authenticity, place-based context, and purpose to a driving task.

\section{METHODS}

\section{Program Context}

This study is situated within a teacher education program rooted in social justice. It exclusively places student teachers in the socioeconomically challenged areas and engages and learns with the community through targeted assignments, reflection, and humanizing pedagogy. Developing an asset-oriented community focused on humanizing STEM teachers embodies the values of the teacher education program. Pre-service math and science teachers engage in this work concurrently as a STEM cohort.

The length of the teacher preparation program is 24 months. Pre-service teachers attain their credentials the first year of the program and complete a Master's in Education during the second year. The study occurs within the context of a first-year seminar course focused on the intersection of theory and practice with families and the community. The implementation of C-STEM-PBL predominantly occurs in a large urban school district with a majority-minority population and a district-wide Title 1 population of $75.7 \%$, where more than $25 \%$ of the students are second language learners. This study articulates pre-service teachers' initial design and implementation of C-STEM-PBL and what they learned from the process. 


\section{Participants, Reflections, and Coursework}

31 pre-service math and science teachers have participated in at least 7 courses as a STEM cohort with 2 faculty advisors. In the third quarter of the program, the pre-service teachers were asked to develop and implement a community-focused STEM- PBL (Appendix A). C-STEM-PBL presents a culmination of pedagogical development that results from a critical examination of race, class, gender identity, and privilege as it relates to their positionality. Further, in the third quarter, pre-service teachers have engaged in extensive planning and assessment development as well as having completed the edTPA process. Within the C-STEM-PBL assignment, pre-service teachers constructed a PBL lesson plan, a graphic organizer depicting C-STEM-PBL, a final reflection, and K-12 student artifacts. Both the C-STEM-PBL reflections and the C-STEM-PBL graphic organizers were coded for themes. Categories of information were developed from the text (open coding) and then connected (axial coding) into generative themes (Corbin \& Strauss, 2014). We are currently analyzing, through the same process, another cohort of 28 STEM preservice teachers that we will include in the study.

\section{Data Sources}

1. C-STEM-PBL - graphic organizer that includes the driving question, task assessment, technology, audience, and how the community will be embedded. (Appendix B)

2. Reflections on implementation (see Table 1 and Appendix C)

3. Student artifacts (see Table 1)

\section{RESULTS}

\section{Community-Centered and Authentic Learning}

According to the work of Ziechner, Payne \& Brayko (2015), who conceptualize a third space in teacher development, the learning must be authentic and community-centered. While there were many examples of learning that were contextualized, there were fewer examples of tasks tied to the community in authentic meaningful ways. Although, $41 \%$ (Figure 1a) of candidates constructed driving questions that were tied to the community such as the following: (Table 2)

1. How does where you live affect how you live?

2. How can we reduce our carbon footprint?

3. How do GMO's affect our food, our community, and our environment?

4. How can we use Geometry to help solve the needs of our community?

5. How can statistical inference help understand issues in our community we care about?

However, the predominant form of community engagement consisted of presenting to families/community (Figure 1c) at $57 \%$. More authentically, $22 \%$ of these accessed family/community feedback, and only $8 \%$ tied their project to a form of advocacy (Figure 1c). These projects involved connections to issues in their communities (Table 1).

Pre-service candidates were able to implement contextualized learning, at $87 \%$ (Figure 1a and Table 2 ). In science, connections to human impact on climate change and biodiversity were more prominent, and in math, connections to functions and their visibility or application in real life were evident (Table 2).

\section{Deep Learning}

Deep learning by pre-service teachers and community teachers involves reflection on self, identity, and ties to social justice. $70 \%$ of candidates or more saw implementing as a worthwhile experience that benefited their students, Figure 2a, and themselves, Figure 2b. More specifically, a candidate noted that this pedagogical approach renewed their purpose and vision in teaching.

"Reminded of why got into teaching and what they hoped teaching would be like. Would like to do more." S1 - Table 1 
Preservice teachers noted it was possible to connect content to Social Justice issues and to create a CSTEM PBL tied to student interests. Over $80 \%$ of participants plan to implement this pedagogy as firstyear teachers (Figure 2c).

\section{General Learning}

A characteristic of PBL is making the presentations public (Larmer et al., 2015). Figure $1 \mathrm{~b}$ depicts $67 \%$ of students presenting to the community, families, including school functions. Similar to Demirel, \& Dağyar. (2016), pre-service teachers learned that students enjoyed this approach.

About enjoyment and engagement, some teachers noted the following:

"...how invested students were in the project" "I was so surprised by how much my students enjoyed doing the PBL! They wanted to do more and take on the biggest challenges." "What surprised me about implementing my PBL was how excited students were to do the assignment one they began" (Pre-Service Teacher comments - Reflection)

Additionally, pre-service teachers noted that their K-12 students learned both content and skills such as collaboration and were more comfortable with greater autonomy. Developing greater autonomy among students aligns with tenants of PBL. Learning to be more autonomous and self-manage and is a life skill.

Further, although planning and implementing PBL was a challenge regarding time and being in a guiding teacher's classroom, a positive was that some pre-service teachers noted that the checkpoints inherent in the PBL structure were great opportunities for feedback and formative assessments. Having planned and embedded formative assessments as checkpoints in the PBL process relieved some stress and provided greater direction in the course of implementing PBL.

\section{Challenges and Implications}

The logistics related to implementation proved the most challenging for most pre-service teachers. Getting a sense of timing as it relates to when for how long and how to implement the C-STEM-PBL in someone else's classroom with a specific pacing plan was difficult. In the cohort interdisciplinary seminar course, we ameliorated some of the challenges by planning, sharing, and reflecting on the C-STEM-PBL task and analysis of student work artifacts. The seminar became a space for professional reflection and learning among peers where learning is applied and transferred in a productive space. As a program, we can support the development of more effective formative assessments during the PBL process, introduce the C-STEM-PBL approach sooner and push toward more critical engagement with the community for transformative change.

\section{SCHOLARLY SIGNIFICANCE}

The enactment of C-STEM-PBL offers a pedagogical vehicle that aligns with the characteristics of a community teacher focused on culturally responsive and humanistic pedagogy. Greater connections to specific tools and scaffolds are necessary to better bridge to practice as well as more structured reflective support. Further, C-STEM-PBL allows pre-service teachers and their students to connect to the richness of assets that are inherent in the people, cultures, and institutions of a community. C-STEM-PBL is a concrete pedagogical approach that can challenge K-12 students to think critically and act in community grounded circumstances. Our teachers have the amazing privilege to work with and stand with youth, their families, and their communities so that together, they can work towards transformative possibilities and where all of us can contribute toward our educational responsibility for a greater societal good. 


\section{REFERENCES}

Baran, M., \& Maskan, A. (2010). The effect of project-based learning on pre-service physics teachers' electrostatic achievements. Cypriot Journal of Educational Sciences, 5(4), 243-257.

Bartolomé, L. (1994). Beyond the Methods Fetish: Toward a Humanizing Pedagogy. Harvard Educational Review, 64(2), 173-195.

Corbin, J., \& Strauss, A. (2014). Basics of qualitative research: Techniques and procedures for developing grounded theory. Sage publications.

Darling-Hammond, L., Oakes, J., Wojcikiewicz, S., Hyler, M.E., Guha, R., Podolsky, A., . . Harrell, A. (2019). Preparing teachers for deeper learning. Cambridge, MA: Harvard Education Press.

Demirel, M., \& Dağyar, M. (2016). Effects of Problem-Based Learning on Attitude: A Metaanalysis Study. Eurasia Journal of Mathematics, Science \& Technology Education, 12(8).

Dewey, J. (1938). Logic, the theory of inquiry. New York: Holt Publishing.

Domínguez, C., \& Jaime, A. (2010). Database design learning: A project-based approach organized through a course management system. Computers \& Education, 55(3), 1312-1320.

Engeström, Y. (2001). Expansive learning at work: Toward an activity theoretical reconceptualization. Journal of Education and Work, 14(1), 133-156.

Geimer, E. (2014). The Efficacy of Mathematics Education. The STEAM Journal, 1(2), 14.

Han, S., Capraro, R., \& Capraro, M.M. (2014). How science, technology, engineering, and mathematics (STEM) project-based learning (PBL) affects high, middle, and low achievers differently: The impact of student factors on achievement. International Journal of Science and Mathematics Education, pp. 1-25.

Han, S., Capraro, R., \& Capraro, M.M. (2015). How science, technology, engineering, and mathematics (STEM) project-based learning (PBL) affects high, middle, and low achievers differently: The impact of student factors on achievement. International Journal of Science and Mathematics Education, 13(5), 1089-1113.

Han, S., Capraro, R.M., \& Capraro, M.M. (2016). How science, technology, engineering, and mathematics project based learning affects high-need students in the US. Learning and Individual Differences, 51, 157-166.

Kaldi, S., Filippatou, D., \& Govaris, C. (2011). Project-based learning in primary schools: Effects on pupils' learning and attitudes. Education 3-13: International Journal of Primary, Elementary and Early Years Education, 39, 35-47.

Kilpatrick, W.H. (1918). The project method. Teachers College Record, 19, 319-335.

Kretchmar, K., \& Zeichner, K. (2016). Teacher prep 3.0: A vision for teacher education to impact social transformation. Journal of Education for Teaching, 42(4), 417-433.

Ladson-Billings, G. (2009). The dreamkeepers: Successful teachers of African American children. John Wiley \& Sons.

Larmer, J., Mergendoller, J., \& Boss, S. (2015). Setting the standard for project based learning. ASCD.

Murrell, P.C., Jr. (2000). Community teachers: A conceptual framework for preparing exemplary urban teachers. Journal of Negro Education, pp. 338-348.

Zeichner, K., Payne, K.A., \& Brayko, K. (2015). Democratizing teacher education. Journal of Teacher Education, 66(2), 122-135.

Weissmann, G.S., Ibarra, R.A., Howland-Davis, M., \& Lammey, M.V. (2019). The multicontext path to redefining how we access and think about diversity, equity, and inclusion in STEM. Journal of Geoscience Education, 67(4), 320-329. 


\section{APPENDICES}

FIGURE 1A

C-STEM-PBL DRIVING QUESTIONS PATTERNS

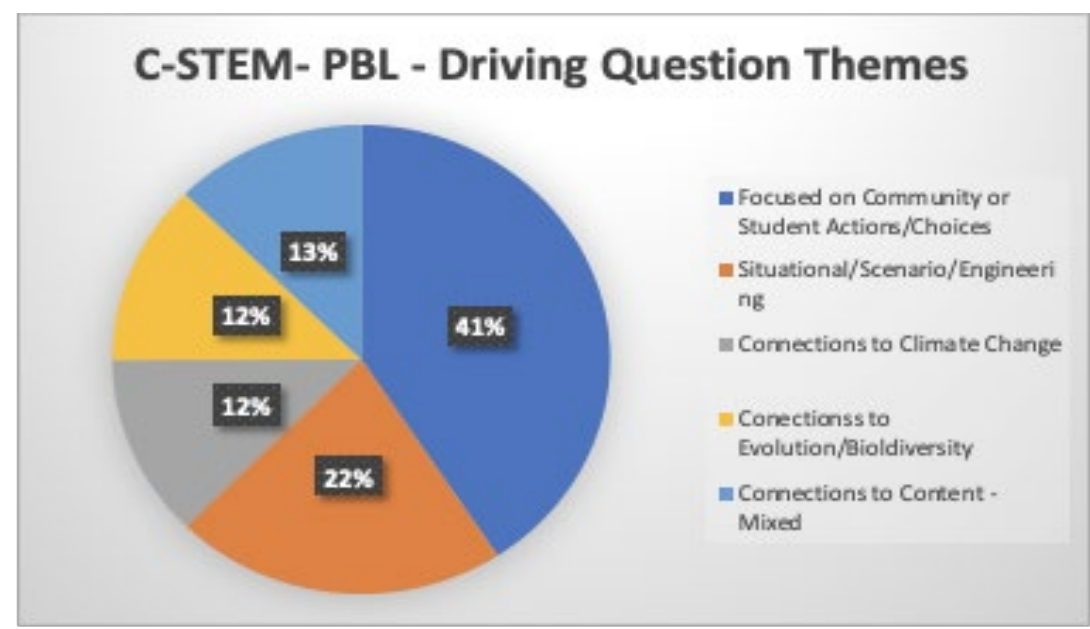

FIGURE 1B

THE AUDIENCE FOR THE C-STEM-PBL

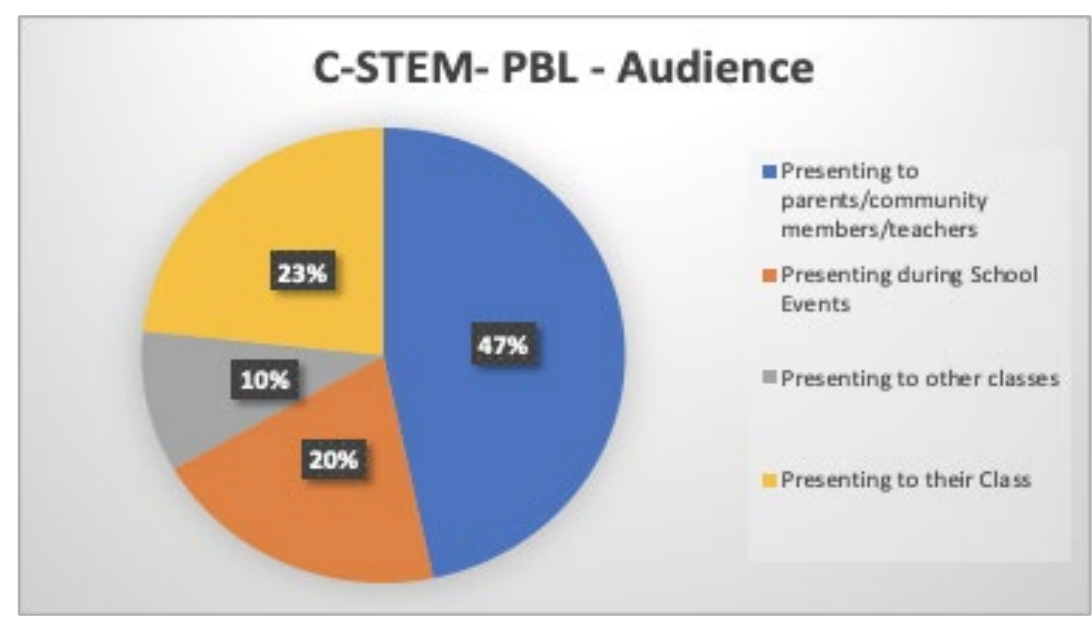

222 Journal of Higher Education Theory and Practice Vol. 21(9) 2021 
FIGURE 1C

HOW PRE-SERVICE TEACHERS ENGAGED COMMUNITY AND FAMILIES

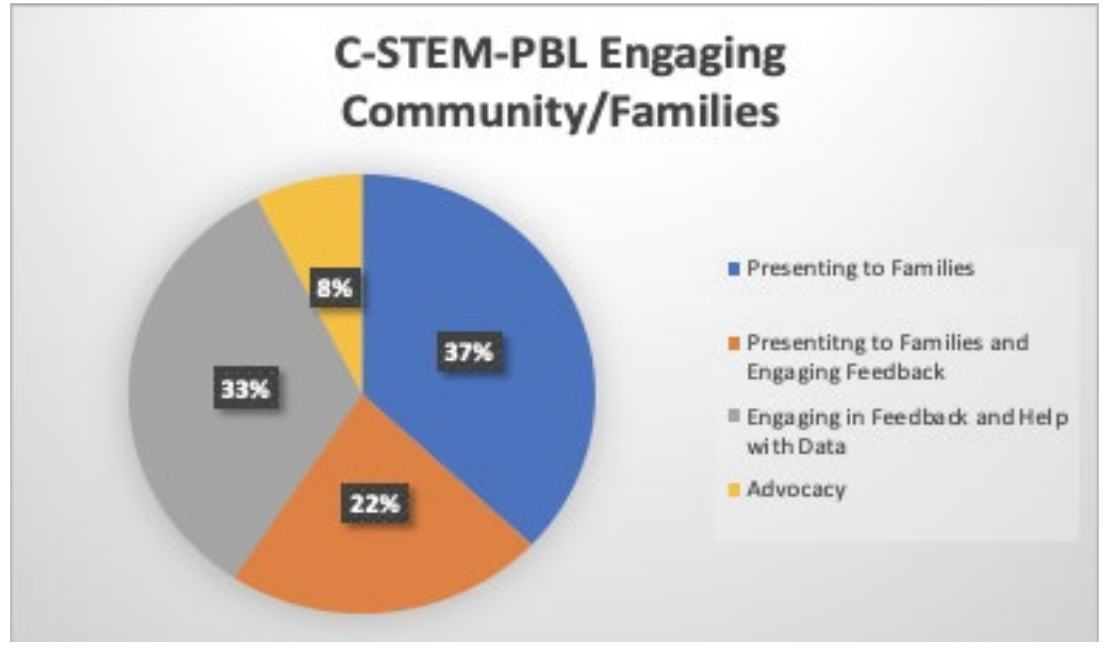

FIGURE 2A, 2B \& 2C

2a. Overall, do you think the end of the year project (PBL) was beneficial for your students?

Overall, do you think the end of the year project (PBL) was beneficial for your students?

30 responses
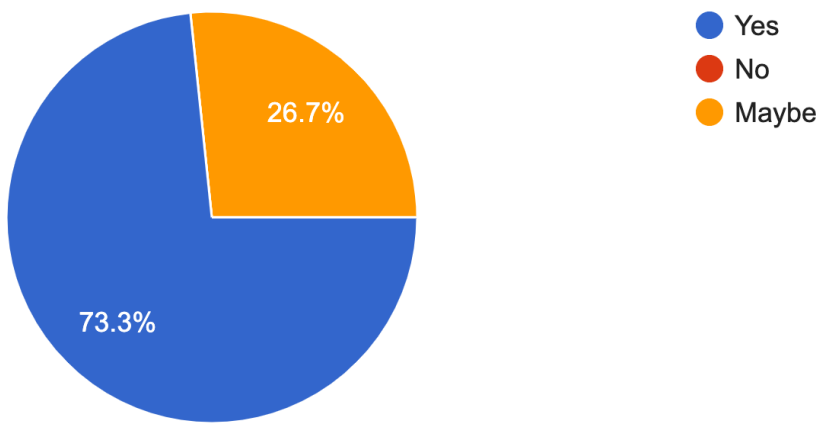

2b. Overall, do you think the end of the year project (PBL) was beneficial for you? 


\section{Overall, do you think the end of the year project (PBL) was beneficial for you?}

30 responses

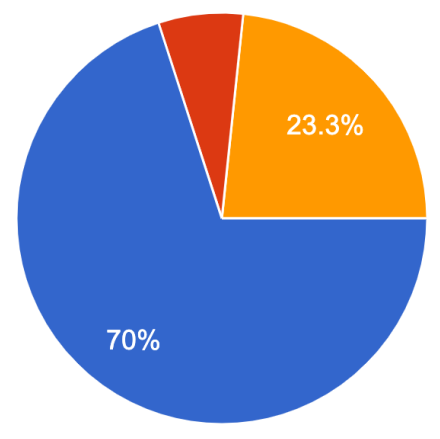

2c. Do you think you will do PBL with your students during your resident year?

\section{Do you think you will do PBL with your students during your resident year?}

\section{0 responses}
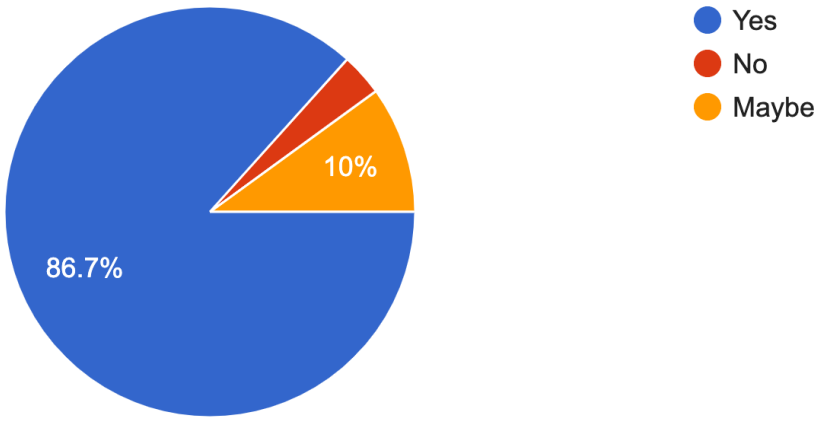

Figures 2a, 2b, 2c. Figure 2a depicts pre-service teacher responses to the perceived benefits of implementing PBL for k-12 students. Figure $2 b$ depicts pre-service teacher responses to the perceived benefits of implementing PBL for themselves. Figure 2c depicts pre-service teacher responses if they would implement PBL the following year as first year teachers. 


\section{TABLE 1}

\section{PRE-SERVICE TEACHER REFLECTIONS ON PBL, STUDENTS, AND SOCIAL JUSTICE}

TEACHER IDENTITY

The driving question, reflection responses, and student work artifacts are depicted. These examples are characterized by more authentic connections to the community and/or families. For S5, student artifacts were not included due to identifiable images of k-12 students.

\begin{tabular}{|c|c|c|c|}
\hline \multicolumn{4}{|c|}{ Questions } \\
\hline $\begin{array}{l}\text { What was your biggest } \\
\text { worry/need as you } \\
\text { began this assignment? }\end{array}$ & $\begin{array}{l}\text { What surprised and/or } \\
\text { challenged you about } \\
\text { implementing/planning } \\
\text { the PBL? }\end{array}$ & $\begin{array}{l}\text { What do you feel } \\
\text { your students } \\
\text { learned and what } \\
\text { might you modify? } \\
\text { Why? }\end{array}$ & $\begin{array}{l}\text { What have you learned } \\
\text { about yourself as a } \\
\text { social justice educator } \\
\text { during the planning } \\
\text { and implementation } \\
\text { phases of this project? }\end{array}$ \\
\hline \multicolumn{4}{|c|}{$\begin{array}{l}\text { (S1) Driving Q: How can statistical inference help understand issues in our community we care } \\
\text { about? }\end{array}$} \\
\hline $\begin{array}{l}\text { Fitting it in at the end of } \\
\text { the year. }\end{array}$ & $\begin{array}{l}\text { Integrating instruction } \\
\text { as the assignment } \\
\text { unfolded was the } \\
\text { hardest part. Creating a } \\
\text { need for instruction } \\
\text { along the way. My } \\
\text { assignment ended up } \\
\text { being more of an } \\
\text { application of all that } \\
\text { my students learned in } \\
\text { class. }\end{array}$ & $\begin{array}{l}\text { I feel like my } \\
\text { students were able to } \\
\text { apply what they } \\
\text { knew to something } \\
\text { they care about. That } \\
\text { was the power of my } \\
\text { PBL. In terms of } \\
\text { skills, my students } \\
\text { learned a lot about } \\
\text { writing about } \\
\text { statistics and the } \\
\text { writing process. I } \\
\text { would try to do } \\
\text { smaller PBL } \\
\text { assignments the } \\
\text { whole semester. I } \\
\text { wish i scaffolded the } \\
\text { writing a bit more. I } \\
\text { wish i structured the } \\
\text { time a little more } \\
\text { rigidly. }\end{array}$ & $\begin{array}{l}\text { This project reminded } \\
\text { me of why i entered } \\
\text { teaching. It was exactly } \\
\text { what i hoped teaching } \\
\text { would be like. I want } \\
\text { todo more and more } \\
\text { PBL. As much as i can } \\
\text { fit in while addressing } \\
\text { content and can plan } \\
\text { with out going insane. }\end{array}$ \\
\hline
\end{tabular}




\begin{tabular}{|c|c|c|c|}
\hline \multicolumn{2}{|c|}{$\begin{array}{l}\text { STEM VS NON-STEM: A study of wages and } \\
\text { unemployment between majors }\end{array}$} & \multicolumn{2}{|c|}{$\begin{array}{l}\text { Immigrants Do Not Harm Our Communities. } \\
\text { Can We See Immigrants As Assets Now and In } \\
\text { The Future? }\end{array}$} \\
\hline \multicolumn{4}{|c|}{$\begin{array}{l}\text { DO MALE DOMINATED MAJORS MAKE MORE } \\
\text { MONEYTHAN FEMALE DOMINATED MAJORS? }\end{array}$} \\
\hline \multicolumn{4}{|c|}{$\begin{array}{l}\text { Too Social to Sleep: Does socializing and doing } \\
\text { homework cause more or less sleep? } \\
\text { Student work in https://medium.com/@lsutcher }\end{array}$} \\
\hline \multicolumn{4}{|c|}{ (S2) Driving Q: How can people make better choices to live healthier lives? } \\
\hline $\begin{array}{l}\text { How to fit this project } \\
\text { into an already } \\
\text { overloaded curriculum } \\
\text { map. I had already } \\
\text { planned out what we were } \\
\text { doing for the entire spring } \\
\text { and moving it around } \\
\text { would be a huge effort. }\end{array}$ & $\begin{array}{l}\text { It was very } \\
\text { challenging to me } \\
\text { having the PBL } \\
\text { embedded into the } \\
\text { entire curriculum, I } \\
\text { felt like I didn't do a } \\
\text { good job of making it } \\
\text { clear that each lesson } \\
\text { was giving them a } \\
\text { piece to the PBL } \\
\text { project puzzle }\end{array}$ & $\begin{array}{l}\text { I would modify how } \\
\text { much time I spent on } \\
\text { each topic to give } \\
\text { more time to healthy } \\
\text { relationships or } \\
\text { remove it as a } \\
\text { possible topic to } \\
\text { choose if i dont teach } \\
\text { it enough. I would } \\
\text { also include a few } \\
\text { activities/lessons on } \\
\text { critical media literacy } \\
\text { to on ramp the } \\
\text { making of PSA's as } \\
\text { media. }\end{array}$ & $\begin{array}{l}\text { A major takeaway I have } \\
\text { is you need to create the } \\
\text { product on your own as a } \\
\text { teacher before you try to } \\
\text { implement it because } \\
\text { otherwise you wont have } \\
\text { a clear idea of what you } \\
\text { need to do. }\end{array}$ \\
\hline
\end{tabular}




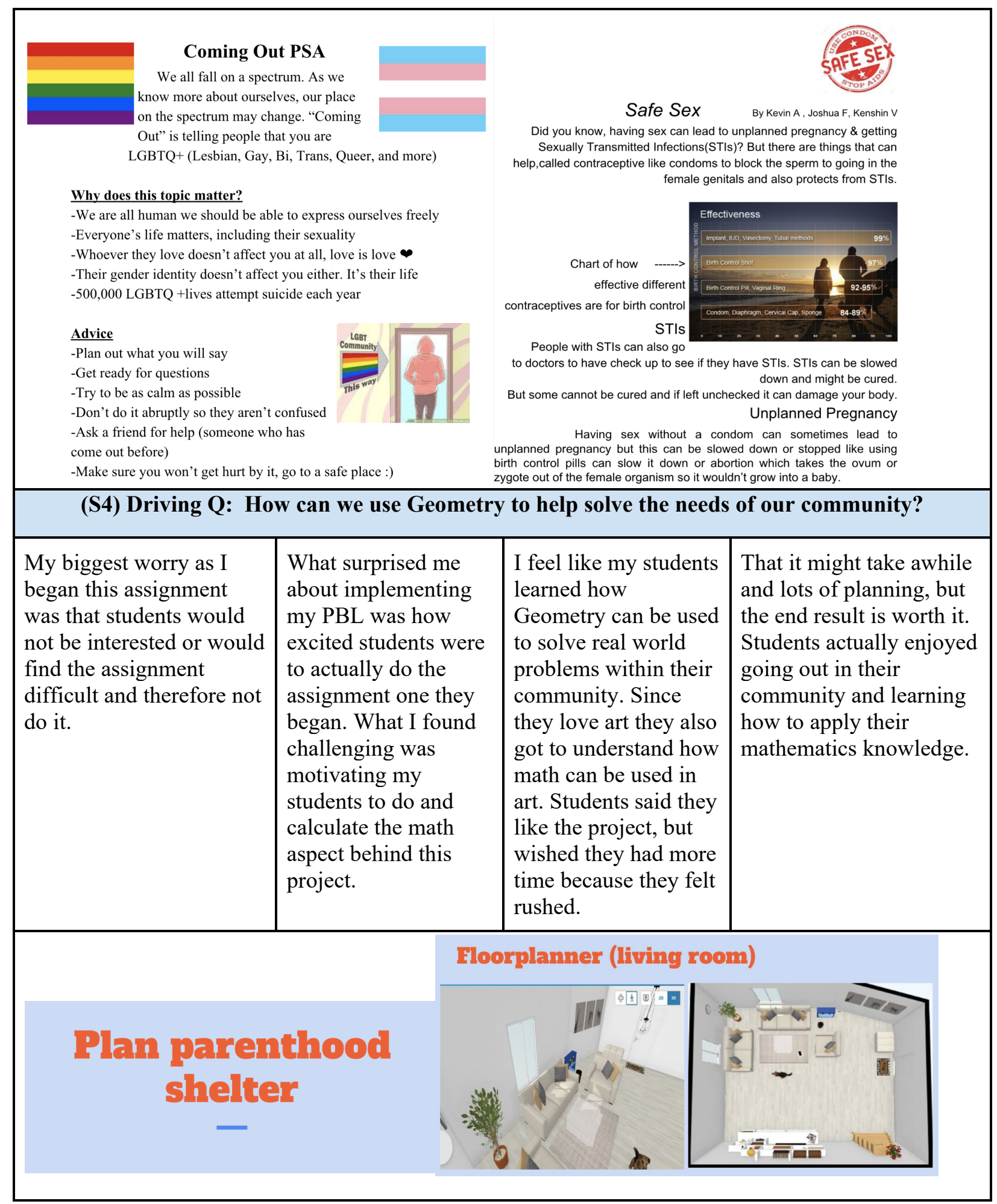




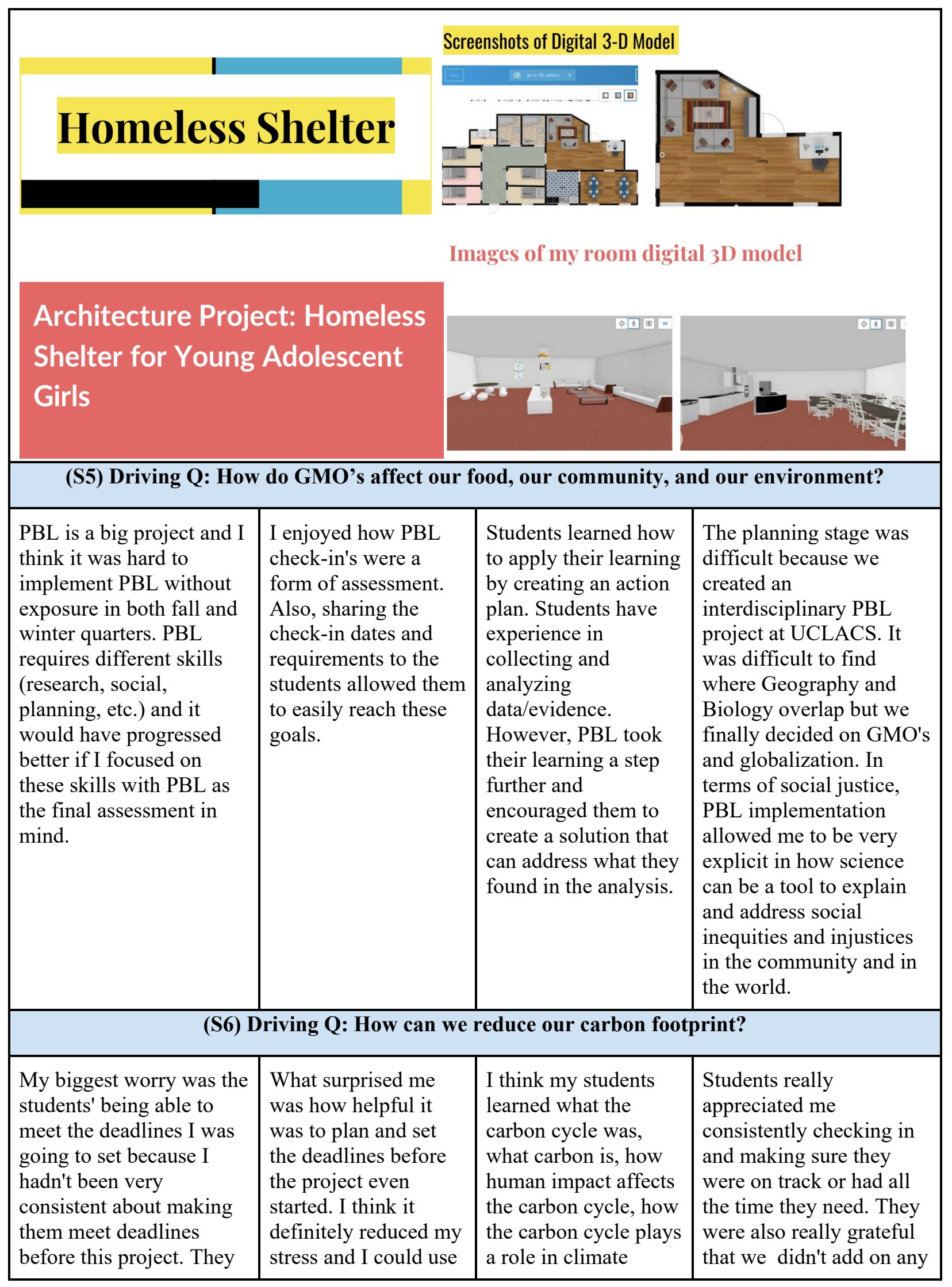




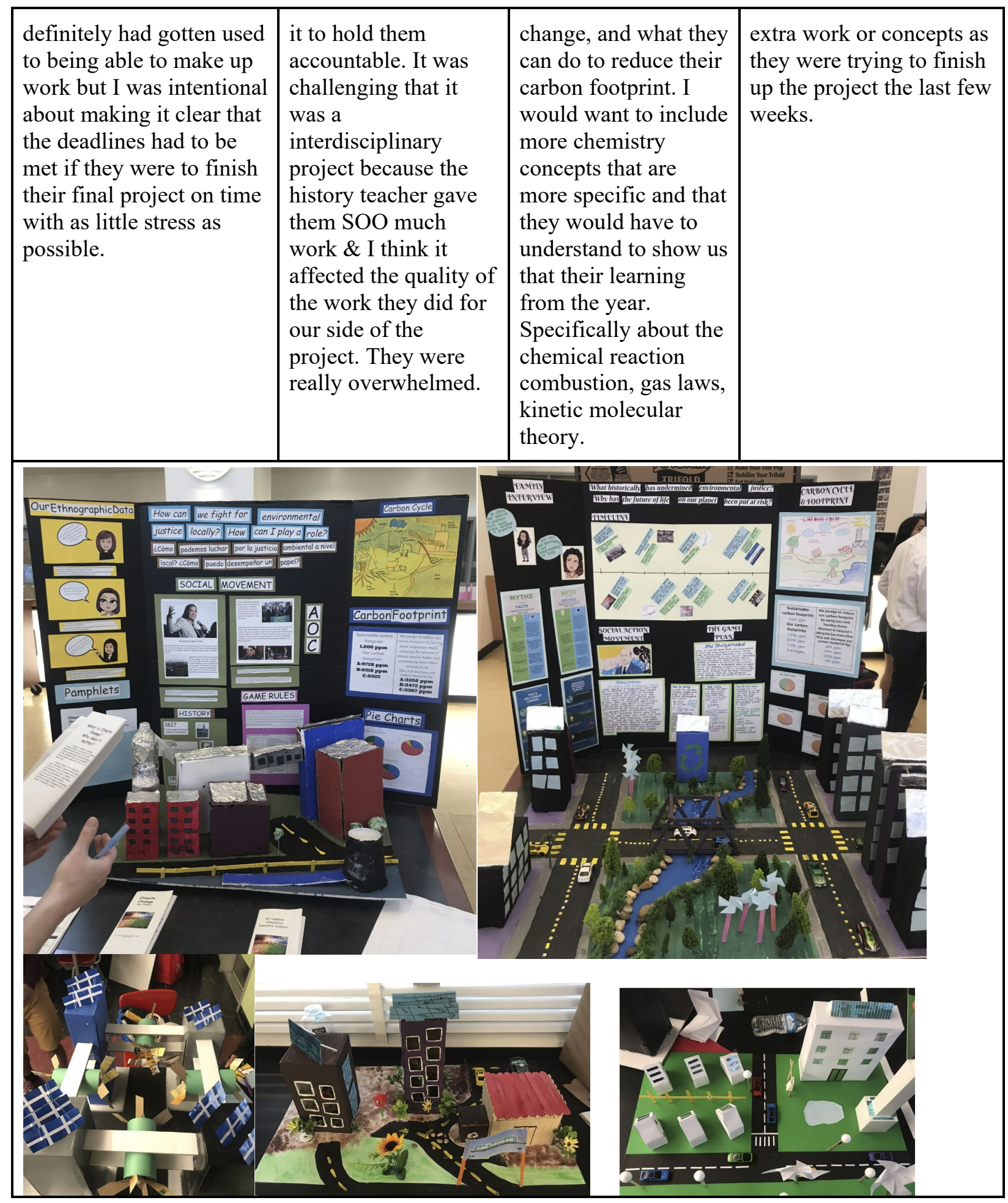




\begin{tabular}{|c|c|c|c|}
\hline \multicolumn{4}{|c|}{ (S7) Driving Q: What can we do to mitigate climate change? } \\
\hline $\begin{array}{l}\text { I was concerned about the } \\
\text { community involvement } \\
\text { aspect because my } \\
\text { students are not that } \\
\text { involved in their } \\
\text { communities yet, nor are } \\
\text { their parents very } \\
\text { involved. }\end{array}$ & $\begin{array}{l}\text { I was so surprised by } \\
\text { how much my } \\
\text { students enjoyed } \\
\text { doing the PBL! They } \\
\text { wanted to do more } \\
\text { and take on the } \\
\text { biggest challenges. }\end{array}$ & $\begin{array}{l}\text { I think my students } \\
\text { learned how to } \\
\text { proactively plan their } \\
\text { own projects and pace } \\
\text { themselves. I think } \\
\text { they learned how to } \\
\text { reach out to } \\
\text { community members } \\
\text { as well. }\end{array}$ & $\begin{array}{l}\text { I have learned that I can } \\
\text { talk on and on about the } \\
\text { importance of thinking of } \\
\text { the environment. I gave a } \\
\text { lot of background on this } \\
\text { topic and really } \\
\text { scaffolded this for my } \\
\text { students and learned that } \\
\text { not all students will be } \\
\text { aware of the problem } \\
\text { from the start. }\end{array}$ \\
\hline & $\begin{array}{r}\mathrm{HE} \\
\text { WO } \\
\text { PLAC } \\
\text { AN } \\
\text { G }\end{array}$ & $\begin{array}{l}\text { P MAKE THE } \\
\text { LD A BETTER } \\
\text { EOR YOU, ME } \\
\text { ALL FUTURE } \\
\text { NERATIONS } \\
\text { Fighin water PouUtion }\end{array}$ & \\
\hline \multicolumn{4}{|c|}{$\begin{array}{l}\text { (S8) Driving Q: What changes can we make to our lifestyle to limit negative anthropogenic effects } \\
\text { affecting our oceans? }\end{array}$} \\
\hline $\begin{array}{l}\text { Since I created my PBL } \\
\text { as a project for the entire } \\
\text { unit, I was worried that } \\
\text { my students would lose } \\
\text { interest in the project } \\
\text { since it stretched over the } \\
\text { course of SIX weeks. }\end{array}$ & $\begin{array}{l}\text { I made a project } \\
\text { management log for } \\
\text { the project, so that } \\
\text { students can be } \\
\text { responsible for small } \\
\text { pieces of the project } \\
\text { and keep each other } \\
\text { in check. Yet, there } \\
\text { were many times } \\
\text { where students came } \\
\text { up to me and } \\
\text { complained how they } \\
\text { did not receive a } \\
\text { grade for a section } \\
\text { because their group- } \\
\text { mate did not complete }\end{array}$ & $\begin{array}{l}\text { My students now } \\
\text { have a greater } \\
\text { understanding for the } \\
\text { importance of clean } \\
\text { water, and the role of } \\
\text { different bodies of } \\
\text { water in Los Angeles. } \\
\text { I plan to show the } \\
\text { next group examples } \\
\text { of each part. } \\
\text { Additionally, } \\
\text { although every part of } \\
\text { the project was public } \\
\text { throughout the } \\
\text { process, I will show } \\
\text { students how to }\end{array}$ & $\begin{array}{l}\text { Localizing the project } \\
\text { really helps with } \\
\text { motivation and } \\
\text { engagement. It is } \\
\text { important to share with } \\
\text { students reliable sources } \\
\text { for information and } \\
\text { realistic actions they can } \\
\text { do to benefit themselves } \\
\text { and society. }\end{array}$ \\
\hline
\end{tabular}




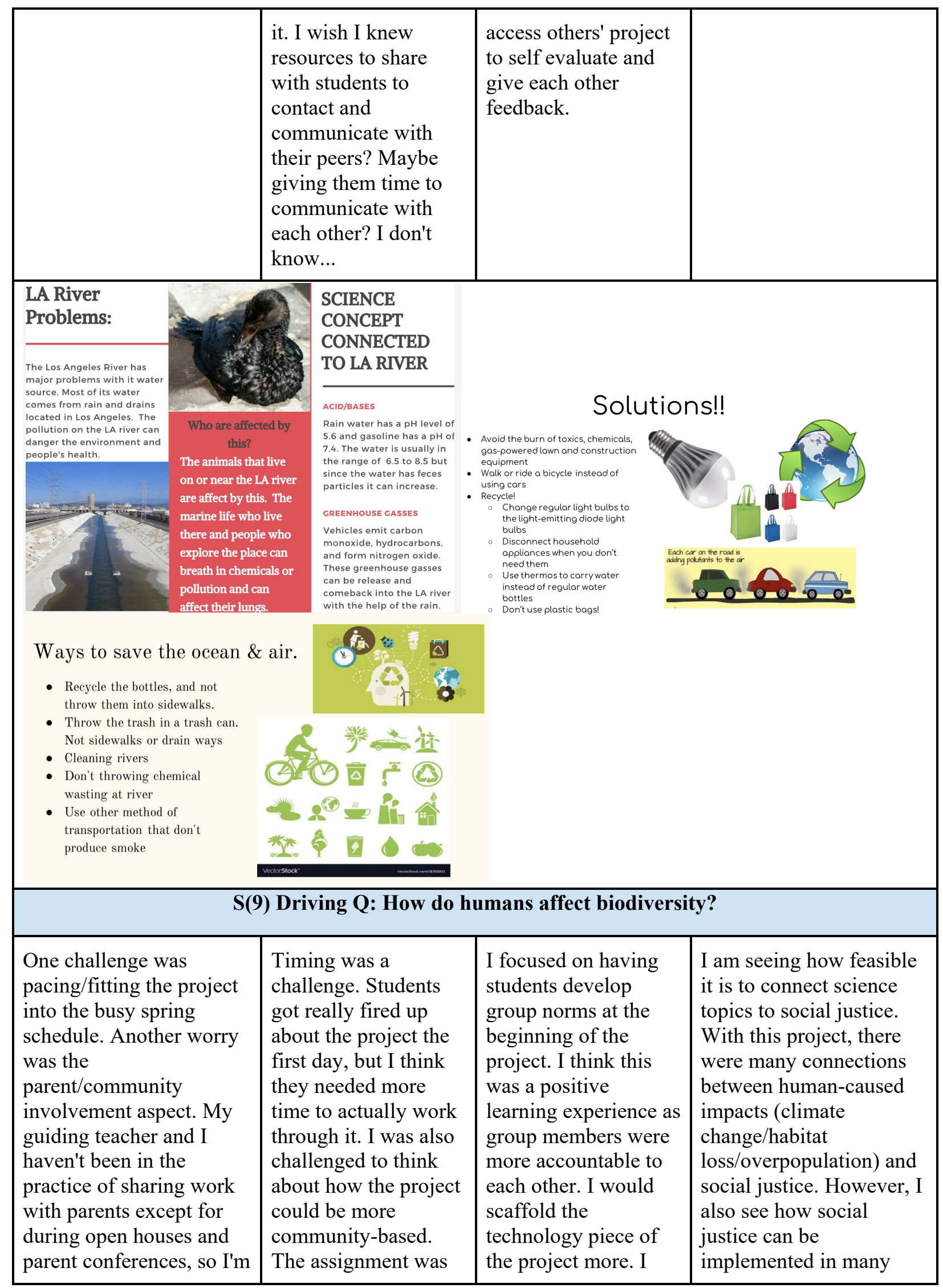




\begin{tabular}{|c|c|c|c|}
\hline $\begin{array}{l}\text { thinking about how next } \\
\text { year I can put these } \\
\text { structures in place from } \\
\text { the start so that sharing } \\
\text { student work with parents } \\
\text { is more routine. }\end{array}$ & $\begin{array}{l}\text { to research a human- } \\
\text { caused impact on } \\
\text { ecosystems, and I } \\
\text { encouraged students } \\
\text { to research areas in } \\
\text { the community but } \\
\text { did not require it. } \\
\text { Some groups did, and } \\
\text { some groups chose to } \\
\text { research areas from } \\
\text { their home countries. } \\
\text { Many decided on } \\
\text { other areas, but I } \\
\text { think this was okay as } \\
\text { it provided a great } \\
\text { range of content. }\end{array}$ & $\begin{array}{l}\text { encouraged groups to } \\
\text { use alternative media. } \\
\text { Some did videos, } \\
\text { wrote poems, etc but } \\
\text { most went with } \\
\text { Google slides. } \\
\text { Perhaps more } \\
\text { scaffolding of specific } \\
\text { technologies would } \\
\text { have encouraged } \\
\text { them to use other } \\
\text { tools. }\end{array}$ & $\begin{array}{l}\text { other ways besides the } \\
\text { actual content. The ways } \\
\text { I differentiate, group } \\
\text { students, develop norms, } \\
\text { and support their research } \\
\text { skills are also parts of } \\
\text { being a social justice } \\
\text { educator. }\end{array}$ \\
\hline \multicolumn{4}{|c|}{$\begin{array}{l}\text { Impacts of Trash/Plastic \& Water } \\
\text { Pollution on MacArthur Park } \\
\text { Pand }\end{array}$} \\
\hline 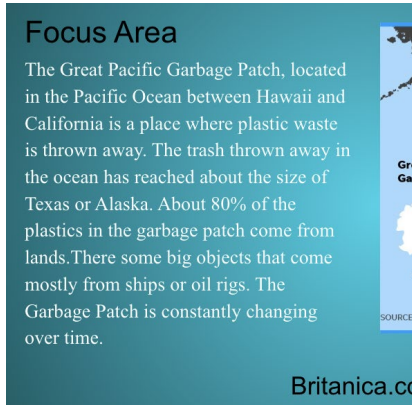 & Ind picture: ustoday.com & $\begin{array}{l}\text { nan-Caused Problem(S) } \\
\text { uman causes on Malibu climate change } \\
\text { uilding more houses on the mountains } \\
\text { arbon Dioxide going up in the air. }\end{array}$ & 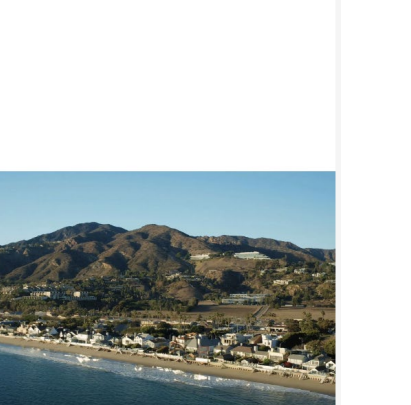 \\
\hline $\begin{array}{l}\text { Solutions - What's Already E } \\
\text { - New nest areas are closed } \\
\text { to the public } \\
\text { Organizations are } \\
\text { publicly educating people } \\
\text { about the problems } \\
\text { - No olonger selling rodent } \\
\text { poison in the Malibu } \\
\text { community }\end{array}$ & All Things Are Connected & $\begin{array}{l}\text { Impacts of Air Pollu } \\
\text { Loss on Los Angele. } \\
\text { Delvin Menedez, Andrew Reyes, and Zuriel } \\
\text { Zarazua }\end{array}$ & tion \& Habitat \\
\hline
\end{tabular}




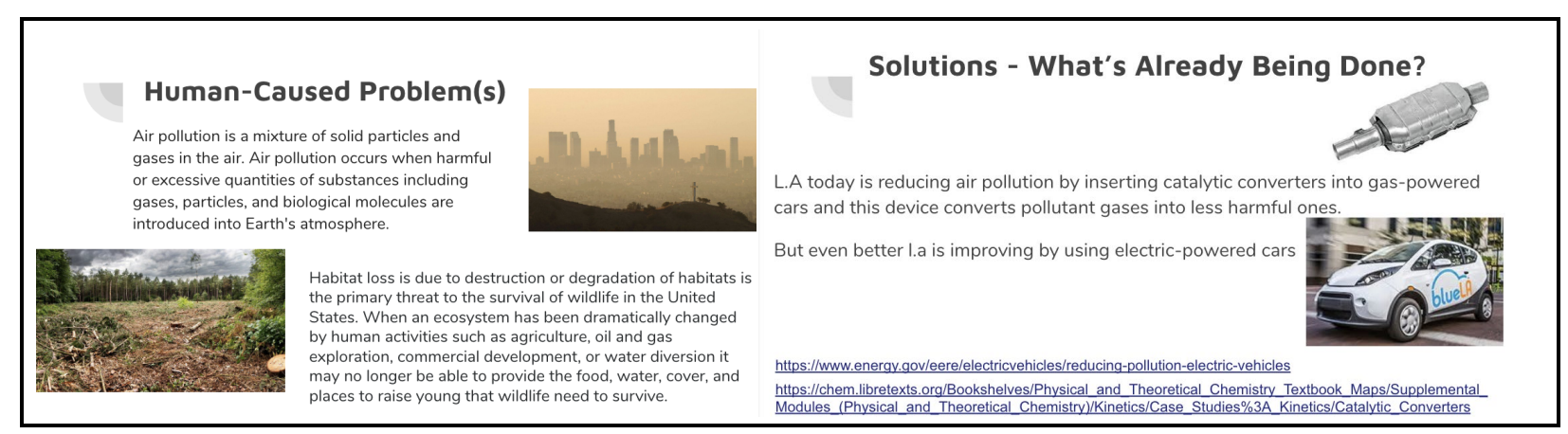

TABLE 2

C-STEM- PBL DRIVING QUESTIONS, AUDIENCE AND COMMUNITY ENGAGEMENT

\begin{tabular}{|c|c|}
\hline \multicolumn{2}{|r|}{ C-STEM - PBL Driving Questions } \\
\hline Math & Science \\
\hline $\begin{array}{l}\text { Focused on Community or } \\
\text { Student Actions/Choices } \\
\mathbf{2 0 \% )} \\
\text { 1. } \\
\text { How can we use } \\
\text { Geometry to help solve } \\
\text { the needs of our } \\
\text { community? } \\
\text { 2. How can statistical } \\
\text { inference help } \\
\text { understand issues in our } \\
\text { community we care } \\
\text { about? } \\
\text { 3. How can we utilize } \\
\text { quadratics to enhance } \\
\text { product design and } \\
\text { develop informed } \\
\text { decisions? } \\
\text { 4. How can we use surveys } \\
\text { to analyze an effect of a } \\
\text { single event on } \\
\text { another?; Students will } \\
\text { be creating their own } \\
\text { driving question based } \\
\text { on their survey question. } \\
\text { 5. How are functions } \\
\text { represented in my } \\
\text { community? } \\
\text { Where can I find a } \\
\text { parabola in real life? }\end{array}$ & $\begin{array}{l}\text { Focused on Community or Student Actions/Choices: (23.3\%) - } \\
\text { Math and Science together - } \mathbf{4 3 . 3 \%} \\
\text { 1. How does where you live affect how you live? } \\
\text { 2. How can we reduce our carbon footprint? (Alexa) } \\
\text { 3. How do GMO's affect our food, our community, and our } \\
\text { environment? } \\
\text { 4. How can people make better choices to live healthier lives? } \\
\text { 5. What changes can we make to our lifestyle to limit negative } \\
\text { anthropogenic effects affecting our oceans? } \\
\text { Situational/Scenario/Build: (13.3\%) - Math and science together } \\
\mathbf{2 3 \%} \\
\text { 1. How can we design a spaceship to safely explore space? } \\
\text { 2. How can we design musical instruments to produce } \\
\text { different sounds? } \\
\text { 3. How can we apply the law of conservation of energy to } \\
\text { create a thrilling roller coaster? } \\
\text { 4. How can we design a functioning model of the digestive } \\
\text { system that consumes food and produces feces? } \\
\text { Climate Change Leading: (13.3\%) } \\
\text { 1. What are solutions for climate change? } \\
\text { 2. What characteristics and adaptations lead to the survival of } \\
\text { species? How does global warming/ human impact drive } \\
\text { evolution? } \\
\text { 3. How can species respond to climate change by evolving or } \\
\text { going extinct? } \\
\text { 4. What can we do to mitigate climate change? } \\
\text { Content: (26.6\%) } \\
\text { 1. Evolution/Biodiversity as a focus: (13.3\%) } \\
\text { 1. How can evolution help organisms adapt to different } \\
\text { 2. What are the effects of evolution on different species and } \\
\text { on humans? }\end{array}$ \\
\hline
\end{tabular}


1. How can we save the most money?

2. How can we get the most food with our budget?

3. How can we find the equation of a parabola whose graph, when plotted, matches our picture?
3. How do humans affect biodiversity?

4. What causes changes in ecosystems that will ultimately affect populations evolution?

2. General - motion, body and chemical structures (13.3\%)

1. How can we use household items to research atomic structure, chemical bonding, and chemical reactions?

2. How will the transformation of energy impact a marble as it travels through a rolling ball sculpture?

3. How does an electric motor work?

4. How does the human body work?

Ways Pre-Service Math and Science Teachers Engage Community

Audience:

Presenting to parents/community members/teachers: (46.7\%)

1. Students will present in class to their peers, parents, and other staff members. Audience will fill out a feedback form for each presenter.

2. Classmates, Parents, Teachers, UCLA Professors

3. Fellow classmates. Potential recruitment of fellow teachers. Possibly contact outside staff related in astronomy.

4. Fellow classmates. Music teacher. Parents. Students can record and show a short demo of their musical instrument.

5. Students will present their train tracks and presentations to other teachers

6. Poster, Classmates, UCLA Business and Math Students

7. Students will present their product to invited community members, families, 9 12th grade students, staff, and other invited guests.

8. Present to the class, teachers, and other staff.

9. Present to the class, teachers, and other staff

10. Other teachers of the school, fellow student teachers

11. Community members (friends or family or social media post).

12. Students will present to their classmates and undergraduate students majoring in environmental studies at UCLA (need active roles) (who is giving feedback?

13. Classmates and faculty members will be present at the presentations of $3 \mathrm{D}$ models.

14. Publications will be shared within the classroom as well as with adults from the school. Presenting during School Events (Open House/Exhibition) (20\%)

1. Parents will see and hear their child's instrument at Open House.

2. Parents, Family, Peers at HTMMA's Exhibition Night

3. Fellow Classmates, Teachers (English, Geography, and Biology), Parents during Open House

4. Parents for back to school/parent night and their own classmates, as well as their communities if they choose to do so

5. Students will present their findings in class and will post their PSAs to a larger audience, depending on the type of media they create. For example, if it's a social media post, they can share it on Schoology or on their social media. If they create a poster or policy proposal they will hang it in the school hallway.

6. Published article and community member comments

Presenting to other classes $\mathbf{( 1 0 \% )}$

1. Students will present to freshman pathways class

2. Students will present to others in the class

3. Pathways Presentation

Presenting to Class $(\mathbf{2 3 . 3 \%})$ 
1. Classmates

2. Student videos will be projected in class for critique

3. Groups are presenting in front of the class while students write down what they understand and the questions they have about that body system.

4. Students will present in front of the class, other teachers, and attending parents.

5. Present in front of the class.

6. Classroom Presentations

7. Students will present their roller coaster to the class and to the "board of directors" (Guiding teacher and I)

\section{Engaging Family/Community:}

\section{Presenting: (37\%)}

1. Students will have opportunity to present to a family/ friend members and be able to have feedback from their family/friends.

2. Parents will be potential audience members for these presentations.

3. Exhibition Night

4. Family \& Friends during open house

5. Students can present to their parents at one of the parent conferences

6. Parents will be seeing students' models at Open House

7. Parents will be invited to the presentations of the new species.

8. Invited into the classroom to view presentations

9. Students will be sharing their PSA with their friends and families, including their parents.

10. Parents in the parent center will also be invited to the presentations.

Presenting and/or Feedback: (22.2\%)

1. Have parents give feedback on student explanation and presentation

2. Students can practice their sales pitch to their parents.

3. Parents will have a conversation with their student(s) about the needs in their community. Come to student presentations. Parents will sign project information page.

4. Parents will be asked to look over students' presentations and give feedback. They will also be invited on presentation day.

5. Parents from the parent center will be present in the audience of presentations.

6. Parents aware of deadlines. Projects presented during the next open house.

Feedback and Help with data -sometimes tied to presenting: (33.3\%)

1. Gathering or looking up restaurant menus

2. Students will practice presentation with parent \& give feedback. Parents are helping students collect recyclables from home for their city build and will be helping students answer questions about their home when calculating their carbon footprint will be invited to Presentation Day.

3. Students may talk to parents about ideas for objects. Parents may drive students to places to find objects

4. Student families will be invited to the presentation. In addition, students are encouraged to learn more about GMO farming by interviewing relatives with farming experience.

5. Parents can help students over break to create their media and do research as well as be their community member interview if the students choose that.

6. Students will be encouraged to talk with their parents when choosing an area to research, and to use parents/siblings/community members as primary sources (via interviews). PSAs will be shared with parents at next CHALC.

7. Parents are encouraged to help students design and build roller coaster. Parents are also encouraged to attend presentations and serve on "board of directors"

8. Parents commenting on the published stories

9. Parents are encouraged to support students with supplies to construct models, students are asked 
to present videos to parents.

Advocacy: ( 7.4\%)

1. Students can advocate for better lifestyle choices to their parents

2. They teach their parents and incorporate something they learn from class to limit their negative effects to the ocean at home.

\section{Appendix A - Assignment Description}

\section{PBL: END OF THE YEAR PROJECT ASSIGNMENT}

In one or both of the student teaching placements, pre-service teachers will plan and implement a CSTEM PBL (Project Based Learning) using elements of PBI (Project Based Instruction) gold criteria from the Buck Institute in an end of the year project. Preservice teachers will use this following book as a resource for planning and implementation:

Larmer, J., Ross, D., Merendollar, J.R. (2017) Project Based Learning (PBL) Starter Kit second edition. Buck Institute for Education.

Your C-STEM-PBL Task should include the following components:

o Student presentation on culturally responsive and/or real life application topic to an audience

o Parents/family/community component

o Technology component

o Rubric and Feedback

Pre-service teachers will have opportunities in seminar to research, plan, edit, and present aspects of the project. Pre-service teachers will complete the Planning Sheets in the PBL Starter Kit Book. Pre-service teachers will upload artifacts and pictures throughout the quarter on Box and Classting.com

Pre-service teachers will submit final project description (planning template in the PBL Starter Kit book*), 3-5 student work artifacts, 10-minute video clip on student presentation, and reflection (using template provided) for a Passing Grade.

\section{Appendix B- Planning - C - STEM-PBL Graphic Organizer}

\section{TEMPLATE [Your Name]: Project Title}

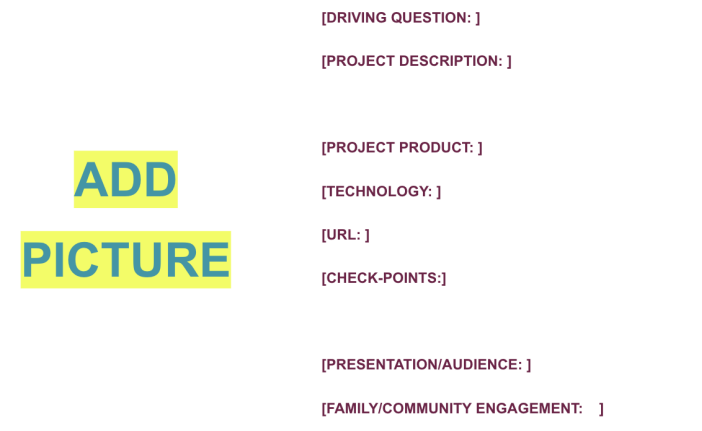




\section{Appendix C - Reflection Questions}

1. What was your biggest worry/need as you began this assignment?

2. What surprised and/or challenged you about implementing/planning the PBL?

3. What do you feel your students learned and what might you modify? Why?

4. What have you learned about yourself as a social justice educator during the planning and implementation phases of this project?

K-12 STEM teachers are essential to the critical analysis of real-world issues and can contribute to the democratization of our society, especially in urban contexts. We engage urban based pre-service STEM teachers in community focused STEM project-based learning (C-STEM-PBL). STEM teachers were challenged by time, scaffolds, and context in their implementation of C-STEM-PBL and noted increased interest and engagement by their students; further, C-STEM-PBL provided opportunities for intentional formative assessments. STEM teachers, through the STEM-PBL process, facilitated opportunities for K-12 students to connect STEM related issues to their personal and community experiences. This place based, high context approach creates opportunities for critical analysis; so, students might push against the injustices that affect the community. 